\title{
KOSAKATA SERAPAN BAHASA JEPANG DALAM KBBI: ANALISIS STRUKTUR DAN MAKNA
}

\section{The Japanese Loanwords in KBBI: Analysis of Their Structuresand Meanings}

\author{
Jerniati I
}

Balai Bahasa Sulawesi Selatan

jernihatiku@gmail.com

\begin{abstract}
Abstrak
Penelitian ini bertujuan mengungkapkan masalah kosakata serapan bahasa Jepang dalam KBBI (Kamus Besar Bahasa Indonesia).Penelitian ini menggunakan pendekatan analisis struktural yang dapat mendeskripsikan kelas kata atau kosakata melalui ciri strukturalnya. Selain itu, penulis juga menggunakan paradigma yang mendukung teori makna leksikal dan makna gramatikal. Selanjutnya, penelitian ini menggunakan metode deskriptif analitis yang bertujuan mendeskripsikan secara empiris berdasarkan situasi atau fakta yang ada dan memaparkan dengan apa adanya. Sumber data utama berasal dari KBBI (2016). Hasil penelitian menunjukkan (1) struktur morfologi kosakata bahasa Jepang dalam KBBI ada dua, yaitu struktur kata dasar dan struktur kata turunan. Kata dasar tersebut adalah kosakata bahasa Jepang yang telah diserap dalam bahasa Indonesia (menjadi penghuni KBBI) dan dapat menjadi dasar bentukan kata, sedangkan kata turunan adalah kosakata bahasa Jepang yang dapat atau telah melewati proses afiksasi (prefiks ber- dan pe-) atau telah melewati proses pemajemukan yaitu penggabungan kosakata serapan bahasa Jepang dengan kosakata bahasa Indonesia. (2) Kelas kata bahasa Jepang dalam KBBI ada tiga, yaitu nomina, verba, dan adjektiva. (3) Makna kata yang terungkap dalam analisis adalah makna leksikal dan makna gramatikal.
\end{abstract}

Kata kunci: kosakata serapan,bahasa Jepang, KBBI

\begin{abstract}
This papper aims to describing loan words of Japanese language in KBBI (Indonesian Dictionary). The research approach uses structural analysis which assumes that part of speech or vocabulary could be described through its structural characteristic. Besides that, the writer uses supporting theory like lexical and grammatical meaning. Moreover, the analysis method is using descriptive analysis in order to describe empirically based on situation or facts that existed and explained. The main data is Indonesian Dictionary . The result of analysis shows that: (1) Morphological structure of Japanese language vocabulary in Indonesian Dictionary consists of two, base form and derivation form. Base form is Japanese language words that have been absorbed in Indonesian language (found in Indonesian Dictionary) and could be the base of derived form, whilst derivation form is Japanese vocabulary that has undergone affixation process (prefix ber-and pe-) or
\end{abstract}


compound process that combines loan words of Japanese language and Indonesian words. (2) There are three part of speech of Japanese language found in Indonesian Dictionary. Namely; noun, verb, and adjective. (3) The meaning of the words exposed in analysis is lexical and grammatical meaning.

Keywords: loan words, Japanese language, Indonesian Dictionary

How to Cite: I, Jerniati. (2019). Kosakata Serapan Bahasa Jepang Dalam KBBI: Analisis Struktur dan Makna. Ranah: Jurnal Kajian Bahasa, 8 (1), 77-91. doi: https://doi.org/10.26499/rnh.v8i1.938

\section{INTRODUCTION}

Among Indonesian people, Japanese colonization period is considered as one of major milestones in the history of Indonesian language development. During that time, the Japanese people were determined to diminish all Dutch senses by banning Indonesian people to use Dutch language and obliging them to use their own Indonesian language. It enabled the Indonesians to develop raise their status. This Japanese policy was one of linguistic politics incredibly giving advantages to the Indonesians (Permadi \& Murtiningsih, 2015)

Seventy-seven (77) years have passed, the relation created between Indonesian and Japanese languages is more developing. It is proven by the fact that Indonesia is ranked second as a country whose people learning the Japanese language come in a great number. According to the data of Japan Foundation 2012, there were 872,411 Japanese language learners in Indonesia. The number came after China whose 1.046 .490 people learned the language. In fact, Japanese learners in Indonesia have high motivation in learning since Japanese language is one of difficult languages to learn. It is in accordance with statements that Japanese language has many structures and its diversity becomes one of reasons that makes Japanese language difficult to learn and understand by the learners. Indeed, foreigner language whose mother tongue is different in typology with Japanese language like bahasa Indonesia (Iriantini, 2013).

The dynamics of Japanese language development are increasing year by year in Indonesia. Formally, Japanese language education has developed for more than fifty years. Today, the researcher has Japanese words loaned in our language as listed on KBBI (Kamus Besar Bahasa Indonesia) V, either in forms of offline, online, or printed. The number is not significant, about 100 words (see online Japanese KKBI, $5^{\text {th }}$ edition). However, Indonesian Wikipedia states that there are 118 words contained in free 
encyclopedias. In this study, the researcher selected the Japanese loanwords contained by $\mathrm{KBBI}$, considering that words listed there were standard vocabularies that could be considered as the main reference of this study

Loanwords are words loaned from another language and modified in accordance to the recipient language (Sugono, 2008). Loaning foreign words or terms aims for several importance that are: 1) to improve inter-transibility between foreign and Indonesian languages, 2) to make foreign texts more understandable for Indonesian readers, 3) to make the words more brief and shorter than their translation, 4) to raise agreement among experts if the translation contains too many synonyms, 5) to diminish their chances for having any bad connotation (Indonesia, 2009).

Furthermore, the loaning process emphasizes on the visual form. The process aims to fix both spelling and pronunciation or fix either spelling or pronunciation only. In the Japanese loanwords canoyu, judo, karate, and so on, the process is fixation of both spelling and pronunciation although the spelling is Romanized.

Based on the above explanation, problems discussed in this study are what the basic structures and Japanese loanwords consisted in KBBI are and what speeches of words and word meanings found in Japanese loanwords?

\section{THEORETICAL BASIS}

Morphology is a part of linguistic structures covering words and their parts. Whorf (in Kridalaksana, 2007) also considers morphology as a subsystem of process modifying lexemes into words. Hence, this study refers to arguments developed by structuralists (Kridalaksana, 2008a). Words are a combination between morphemes through affixation, reduplication, and compounding to form. Word is the largest morphological form; while morpheme is the smallest one (Jerniati, 2013).

The identification can be conducted by employing a structural analysis, an approach or theory arguing that classes of words can be described through their structural characteristics (Nida, 1970). Classes of Japanese loanwords contained in KBBI may be originated from various classes of words.

The categorization is based on a theory of classes of words conveyed by (Kridalaksana, 2008b) stating that class of words is a word categorization with similar formal characteristics and classification of noun, adjective, and others to create simple 
grammatical rules. Formal characteristics of classes of words are distinguished from one language to another. Nevertheless, if observed from semantic perspectives, there is always similarity among them; such as the class of word of noun that usually represents a person or thing.

The experts' statements about morpheme, loanwords, structure, and semantical meaning are very suitable with the focus of this research. Therefore, the researcher choose this statement as basic and fundamental theories of this research analysis.

Loanwords possess a basic or distinguished meaning they derive from their origins. However, after being loaned, the meaning usually shifts due to meaning expansion from the basic one or positional changes in the words' lexical element orders. In this research, the researcher hired theories of both grammatical and lexical meanings as a 'scalpel' to analyze Japanese loanwords.

Lexical word meaning is a meaning of linguistic elements as a symbol of particular thing, event, and so on. Linguistic elements has the lexical meaning separately by not regarding its context (Djajasudarma, 2013:16). Therefore, lexical meaning is a meaning existing in the dictionary. In line with it, Chaer (2013:60) believes that lexical meaning is meaning whose characteristics are lexicon, lexeme, or word.

Furthermore, grammatical meaning is a meaning existing as a consequence of affixation, reduplication, and composition processes (Chaer, 2013)., grammatical meaning is a meaning involving an inter-language or meaning relationship that appears as a consequence of word function in a sentence (Djajasudarma, 2013). For example, the based word sumo is affixed with the prefix pe-. The affixation generates a new grammatical meaning that is pesumo, a sumo athlete. The example of its use in a sentence is 'Pesumo Indonesia itu berhasil menjatuhkan lawannya'.

\section{RESEARCH METHOD}

The researcher used written data in forms of Japanese loanwords, taken from offline, online, and printed KBBI $5^{\text {th }}$ edition, (Bahasa, 2016). Besides, the researcher also took the data from popular writings and both unpublished and published results of linguistic research. Oral data were data collected from informants with knowledge and understanding of necessary data (interview with Yamaguchi, 2018). 
This research utilized a descriptive analysis method aiming to empirically describe and truly expose the subject, based on existing situation or facts. Then, the researcher gathered the data by applying the observation method ((Sudaryanto, 1993), investigating Japanese loanwords in KBBI, $5^{\text {th }}$ edition, also from Indonesian Wikipedia as complements. The researcher wrote them down altogether..Data selection process was applied by choosing 1) data which are tightly bounded with Indonesian language, such as karate, yoga, judo,karoke, bonsai, etc. 2) data which are not really well known generally but written officially in KBBI, such as panko, nori, hentai, kabuki, etc.

Meanwhile, the researcher completed the analysis by employing the structural morphological theory, observing both basic and derivative structures of Japanese loanwords contained by KBBI and classifying classes of words by analyzing meanings of words based on their grammatical and lexical meaning. It aimed to figure out an optimal investigation realization.

\section{DISCUSSION}

\section{Japanese Loanword Meanings and Structures}

In KBBI, Japanese loanword structures are categorized into two: the basic and derivative structure. The basic structure is originated from Japanese basic words or morphemes thoroughly loaned to be Indonesian roots. This basic structure commonly contains of lexical meaning or dictionary meaning. Meanwhile, derivative structures are originated from its roots derived by several methods: 1) affixation by adding Indonesian affixes that are prefix, infix, suffix, and confix; 2) compounding, 3) reduplication, and 4) acronym. Vocabularies having a derivative structure or expansion from one of those four methods commonly have grammatical meanings.

These are Japanese loanwords that are Indonesian basic forms with lexical meanings:

\section{Roots}

$\begin{array}{ll}\begin{array}{l}\text { Example } 1 \\ \text { anime (アニメ?) } \\ \text { bonsai (盆栽?) }\end{array} & \begin{array}{l}\text { anime [anime] 'the Japanese animation } \\ \text { bonsai [bonsai] 'a mini tree planted in a mini } \\ \text { pot' } \\ \text { dan [dan] 'a level in Japanese sports (karate, } \\ \text { jun (段?) }\end{array} \\ \begin{array}{l}\text { judo, etc.)' } \\ \text { origami (折紙?) }\end{array}\end{array}$




\section{ikebana (生花? $\quad$ ikebana [ikebana] 'the art of flower arrangement'}

(Bahasa, 2016))

Vocabularies shown in example 1 were completely loaned from the original language. They were loaned without any customization of pronunciation and spelling. In this case, the Japanese spelling employed was the roman one, not the kanji one. Those five loanwords contain lexical meanings, the same meaning contained by dictionaries.

Affixed words are also loaned in addition to loan the roots, as shown below:

\section{Example 2}

\begin{tabular}{|c|c|}
\hline ikido (合気道?) & $\begin{array}{c}\text { aikido [aikido] 'a Japanese martial art similar to } \\
\text { judo' }\end{array}$ \\
\hline ИКІаба & xidoka] 'an aikido athlete' \\
\hline aido (居合 & $\begin{array}{l}\text { iaido [iaido] 'a Japanese martial art by using a } \\
\text { samurai' }\end{array}$ \\
\hline iaidoka (居合道家?) & iaidoka [iaidoka]'an iaidoathlete’ \\
\hline judo (柔道?) & judo [judo]'a Japanes \\
\hline judogi (柔道着?) & judogi [judogi] 'a spe \\
\hline judoka (柔道家?) & judoka \\
\hline karate (空手?) & $\begin{array}{l}\text { karate } \\
\text { (with el }\end{array}$ \\
\hline karategi ( & karategi [karategi] 'a special garment for karate' \\
\hline karateka & karateka [karateka]'a karate athlete' \\
\hline & manga [mana] 'the Japanese comics' \\
\hline mangaka & mangaka [manaka] 'a manga maker' \\
\hline
\end{tabular}

(Bahasa, 2016)

Vocabularies shown in example 2 was wholly loaned without any customization of either spelling or pronunciation. The loanwords became Indonesian roots with the same lexical meaning as in dictionaries although in the Japanese language, they are all derivatives.

In their origins, the pairsaikido and aikidoka, judo and judoka, and karate and karatek consist of two different forms of words. The first form is the root with a lexical meaning; while the second form is the derivative with a grammatical meaning. The utilization of bound morpheme $-k a$ generates a new meaning that is the doer. In brief, it means a practitioner, player, or athlete; such as a judo athlete or an aikido athlete.

Those two forms were loaned by Indonesian language as roots. In the Indonesian language, the word judo has a lexical meaning 'a martial sport'. If affixed by the prefix 
pe-, it forms pejudo that has a grammatical meaning 'a judo athlete'. The utilization of the word pejudo is more common since despite their same meaning, it is more frequently spoken than judoka. However, the affixed--pe karate (pekarate) is uncommon due to the fact that karateka or pemain karate is more usual.

Besides the bound morpheme $-k a$, there is also the bound morpheme $-g i$ in the words judogi that has a grammatical meaning 'a special garment for judo' and karategithat means 'a special garment for karate'. The two bound morphemes (-ka and gi) were not separately loaned from the roots that are judo and karate.

Example 3

\begin{tabular}{|c|c|}
\hline Origins & Loanwords \\
\hline canoyu (茶の湯) [chanoyu $\left.{ }^{?}\right]$ & $\begin{array}{l}\text { canoyu [canoyu]'the Japanese } \\
\text { tea ceremony' }\end{array}$ \\
\hline dakocan (だっこちゃん) & $\begin{array}{l}\text { dakocan [dakocan] 'a black } \\
\text { plastic doll' }\end{array}$ \\
\hline danco (団長) [danchō?] & $\begin{array}{l}\text { danco }[\text { danco] 'a commander } \\
\text { of PETA' }\end{array}$ \\
\hline ohyo (土俵) [dohyō?] & ohyo [ohyo] 'a sumo arena' \\
\hline dojo (道場) [ $\left.\mathrm{dōjō}^{?}\right]$ & dojo [dojo] 'a training hall' \\
\hline jujitsu (柔術)[jūjutsu?] & $\begin{array}{l}\text { jujitsu [jujitsu]'the Japanese } \\
\text { martial art' }\end{array}$ \\
\hline iaido (居合道) [iaidō? $\left.{ }^{?}\right]$ & $\begin{array}{l}\text { iaido [iaido] 'the Japanese } \\
\text { martial art with a samurai' }\end{array}$ \\
\hline \multicolumn{2}{|c|}{ iaidoka (居合道家(Iaidōka?') iaikido [iaikido] 'an iaido } \\
\hline wazari (技あり (waza-ari? $)$ & $\begin{array}{l}\text { wazari [wazari] 'a judo } \\
\text { winning' }\end{array}$ \\
\hline
\end{tabular}

The loaning process of vocabularies listed in Example 3 was done by customizing their pronunciation and spelling. The spelling is not derived from kanji but Roman ones called romaji (ローマ字Rōmaji ${ }^{2}$ ), the Japanese language in Roman alphabets. It is in relation with loanword theory ((Indonesia, 2009)), and it does not apply contructive analysis with other researches.

\section{Derivatives}

In terms of Japanese loanwords, not all words can be derived by either affixation, compounding, or reduplication. Below are Japanese loanwords derived by affixation and compounding processes. 

1) karate (空手?)
karate [karate] 'a Japanese martial
sport (with empty hands/no weapons)

(Bahasa, 2016)

If affixed by the prefix ber-, the word karate alters into berkarate with a grammatical meaning 'to perform karate'. If combined with another word, the word karate creates a new meaning. For instance, the phrase pemain karate means 'a karate athlete'. Other examples are the phrases pelatih karate that means 'a karate instructor' and pakaian karate that means 'a special garment worn by karate athletes'. Those new meanings due to affixation or compounding processes are grammatical meanings, the example of that can be observed as follows:

1a. Olahraga karate ditandingkan dalam Asean Games. 'Karate is included in the ASEAN Games'.

1b. Pelatih karate itu seorang perempuan. 'The karate instructor is a woman'.

2) jibaku (自爆?) 'jibaku’ [jibaku] 'to attack enemies by hitting them with bodies (that have been equipped with bombs or other explosives); reckless, to act as a daredevil'

In the Indonesian language, the word jibaku changes to be berjibaku with the same meaning as its roots if affixed by the prefix ber-. Nevertheless, the Indonesian word jibaku is not a root but a derivative word. It means that it contains a grammatical meaning 'to attack enemies with bravery to die'. The utilization of those two words is as follow:

2a. Sasuke tewas setelah jibaku 'Sasuke died after performing a jibaku".

2b. Sasuke berjibaku dengan musuh. 'Sasuke is performing jibaku to Enemies'.
3) judo (柔道?) ‘judo’ [judo] 'a Japanese martial sport from Jujitsu, emphasizing on quick movements and balance to attack enemies'

If affixed by the prefix pe- (an allomorph of the prefix per-), the Indonesian word judo becomes pejudo, a judo athlete (judoka) (grammatical meaning). If it is combined with the word pemain, pelatih or pakaian, they form the phrase pemain judo, pelatih judo, 
a judo instructor, or pakaian judo, a special garment for judo. Meanings due to affixation process and the word composition can be observed in the example below.

3a. Pejudo itu berasal dari Indonesia. 'The judo athlete comes from Indonesia'.

3b. Olahraga judo berasal dari Jepang 'Judo originates in Japan'.

4) kanji (漢字?) ‘kanji’ [kanji] 'Japanese alphabets’

In Kamus Besar Bahasa Indonesia, $5^{\text {th }}$ edition kanji is a basic noun consisting of one morpheme and three different meanings. It can only be derived by word combination or compounding. For example, if combined with the word huruf, it transforms into the phrase huruf kanji, Japanese alphabets started to use in the first century B.C., each alphabet depicts one word or morpheme'. Meanings produced by the compounding process can be investigated from the examples below.

4a. Dia belajar membaca huruf kanji 'He learns to read kanji'.

4b. Ia membuat kanji. 'He writes in kanji'.

5) mochi (餅?') 'moci' [moci] 'the Japanese rice cake'

The Indonesian word moci means a rice cake for a New Year celebration, mochitsuki. It is a basic noun consisting of one morpheme. It is unusual for it to undergo the affixation process but it is allowed to have combination or compounding processes. For instance, the word mociis combined by the word kue, creating the phrase kue moci that has the same meaning as the Japanese word mochi.

5a. Kue moci terbuat dari beras ketan. 'Mochi is made of rice'.

5b.Moci adalah kue khas Jepang. 'Mochi is a Japanese special cake'.

6) sakura (桜?'） 'sakura' [sakura] 'cherry blossoms'

The Indonesian word sakura means 'white or pink flowers that blossom during early summer in Japan'. It is a basic noun consisting of one morpheme and only allowed to undergo the compounding process. For example, if combined with the word bunga, it alters into the phrase bunga sakura that contains the same meaning as the Japanese one.

7) karaoke (カラオケ?') 'karaoke’ [karaoke] 'to sing a song by playing its recorded instrumental' 
The Indonesian word karaoke means a kind of pleasure by singing popular songs by playing their recorded instrumentals. If affixed by the prefix ber-, it changes into berkaraoke, to sing in karaoke. Besides, the word karaoke can undergo a compounding process by combining it with the word rumah, rumah karaoke, a karaoke place. The examples are below.

7a. Ibu-ibu itu suka berkaroke. 'The women loves karaoke'.

7b. Rumah karaoke itu milik Syahrini. 'The karaoke place belongs to Syahrini'.

\section{Japanese Classes of Words in Kamus Besar Bahasa Indonesia, $5^{\text {th }}$ edition}

Class of words is defined as a group of words that have similarities in their formal behaviors. The behaviors are diverse among languages. However, if it is semantically observed, there are indeed similar behaviors as nouns that usually represent people or things.

Based on the data, we can conclude that noun is the Japanese word most frequently loaned by the Indonesian language. Below are examples of noun that have been classified based on the categories of things, activities, or meanings contained by one word.

\section{Noun}

\section{Nouns Originating in Japanese Culinary}

\begin{tabular}{|c|c|}
\hline ebi (えび?) [ebi] & dried shrimp \\
\hline mochi (餅? ) [moci] & rice cake \\
\hline $\operatorname{mirin}($ みりん?) [mirin] & $\begin{array}{l}\text { yellow, sweet wine to } \\
\text { cook }\end{array}$ \\
\hline nori (海苔?) [nori] & dried seaweed \\
\hline panko (パン粉?) [panko] & $\begin{array}{l}\text { the Japanese } \\
\text { breadcrumbs }\end{array}$ \\
\hline sake (酒?) [sake] & rice wine \\
\hline sashimi (刺身?) [sashimi] & $\begin{array}{l}\text { the Japanese culinary } \\
\text { made of very fresh raw } \\
\text { meat or fish }\end{array}$ \\
\hline sukiyaki (すき焼き?) [sukiyaki] & a Japanese culinary \\
\hline sushi (すし?) [susi] & a Japanese culinary \\
\hline takoyaki (たこ焼き?')[takoyaki] & $\begin{array}{l}\text { a ball-shaped snack, } \\
\text { filled with octopus or } \\
\text { the kind }\end{array}$ \\
\hline tempura (てんぷら?) [tempura] & $\begin{array}{l}\text { a Japanese culinary } \\
\text { made of battered }\end{array}$ \\
\hline
\end{tabular}


teriyaki (照り焼き?) [teriyaki]

$t o f u$ (豆腐? ${ }^{2}$ [tofu]

udon (うどん?)[udon]

wasabi (わさび?)[wasabi]

yakitori (焼き鳥?') [yakitori]

(Bahasa, 2016)

\section{Nouns Originating in Cultures and Arts}

haiku (俳句?') [haiku]

hentai (変態?) [hentai]

hiragana (ひらがな? $)$ [hiragana]

kabuki (歌舞伎?) [kabuki]

kanji (漢字?) [kanji]

karaoke (カラオケ?') [karaoke]

katakana (カタカナ?) [katakana]

kimono (着物? ${ }^{?}$ [kimono]

mochitsuki (餅搗き?) [mocitsuki]

$n o h\left(\right.$ 能 $\left.\bar{o}^{?}\right)[\mathrm{noh}]$

onagata (女形onnagata?)[onagata]

romaji (ローマ字Rōmaji ${ }^{\text {?) }}$ [romaji]

suiseki (水石?') [suiseki] seafood

a Japanese grilled

culinary

the Japanese soft

soybean curd

thick wheat noodle

a plant processed to be

food seasoning

the Japanese satay a short poem

consisting of three

lines with the pattern

of $5,7,5$

a pornographic

Japanese pop cultural

Product

a Japanese writing

style, one alphabet for one word

a Japanese traditional

theater

a Japanese alphabets

from China

to sing a song by

playing its recorded

instrumental

Japanese alphabets to write loanwords

the Japanese

traditional clothes for both men and women the Japanese new year celebration performed by making mochi together the Japanese musical drama a male actor acting as a woman in kabuki the Romanized Japanese language a naturally shaped rock 
tsuru (鶴?') [suru]

(Bahasa, 2016) considered as an art

a stork origami

\section{Nouns Originating in Japanese Militaries and Colonization}

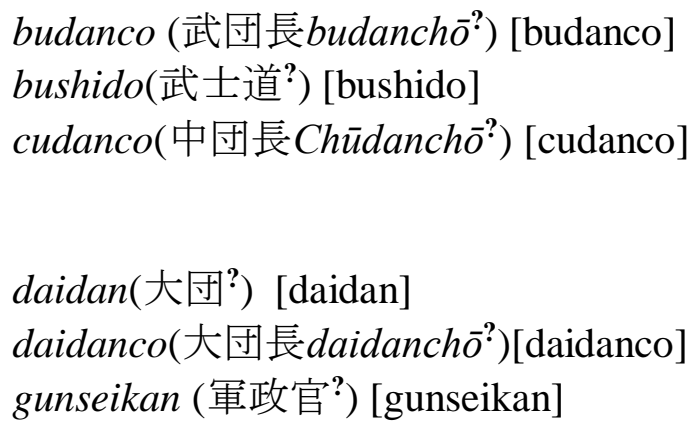

(Bahasa, 2016) a group commander a samurai way of life a captain (a community commander) battalion a battalion commander the Japanese military government during its colonization in Indonesia suicide pilots a Japanese police assistant during its colonization in Indonesia a mechanism to move things Japanese military police during the World War II in Indonesia the head of neighborhood during the Japanese colonization in Indonesia Japanese aristocrats from Japanese soldiers a lieutenant (platoon commander) governors ruling Japan during the $12^{\text {th }}-19^{\text {th }}$ centuries

Indonesian laborers during the Japanese colonization 


\section{Nouns Originating in Sports}

\begin{tabular}{|c|c|}
\hline judo (柔道?)[judo] & a martial sport \\
\hline judoka (柔道家?)[judoka] & a judo \\
\hline & practitioner/athlete \\
\hline kata (形?:) [kata] & $\begin{array}{l}\text { movements in karate, } \\
\text { judo, aikido, etc. }\end{array}$ \\
\hline karate (空手?) [karate] & $\begin{array}{l}\text { a martial sport (with } \\
\text { empty hands/without } \\
\text { weapons) }\end{array}$ \\
\hline ken (拳?) [ken] & $\begin{array}{l}\text { fists, steps in martial } \\
\text { arts (in judo, kempo, etc.) }\end{array}$ \\
\hline kempo (拳法?') [kempo] & a martial art \\
\hline kendo (剣道?) [kendo] & $\begin{array}{l}\text { fencing by using a } \\
\text { bamboo sword }\end{array}$ \\
\hline sumo (相撲? ) [sumo] & $\begin{array}{l}\text { the Japanese wrestling } \\
\text { sport }\end{array}$ \\
\hline taiso (体操?) [taiso] & $\begin{array}{l}\text { the Japanese morning } \\
\text { gymnastics }\end{array}$ \\
\hline yuyitsu (柔術jujutsu? ) [yuyitsu] & $\begin{array}{l}\text { a Japanese martial } \\
\text { sport }\end{array}$ \\
\hline
\end{tabular}

(Bahasa, 2016)

\section{General Nouns}

\author{
emoji (絵文字?') [emoji] \\ koi (鯉?') [koi]

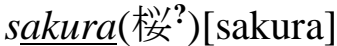 \\ Shinto (神道?) [sinto] \\ sensei (先生?) [sensei] \\ tsunami (津波?) [sunami]
}

yen (円?) [yen]

(Bahasa, 2016) the Japanese

emoticons

decorative fish

cherry blossoms

a religion originating

in Japan

a teacher

a tremendous wave

(due to a strong earthquake occurring in the bottom of the

sea

the Japanese currency

\section{Verbs}

banzai (万歳? ') [banzai]

harakiri (腹切り? ) [harakiri]

jibaku (自爆?) [jibaku]

(Bahasa, 2016)

long live!

to commit suicide for honor

to attack enemies by hitting

bodies equipped with bombs; 
reckless, to act as a daredevil

\section{Adjectives}

\begin{tabular}{|c|c|}
\hline bakero (バケロ bakayarō? ${ }^{?}$ [bakero] & $\begin{array}{l}\text { fool, dumb (a Japanese } \\
\text { swear word) }\end{array}$ \\
\hline ipon (一本? ${ }^{?}$ ) [ipon] & $\begin{array}{l}\text { an absolute winning in } \\
\text { judo }\end{array}$ \\
\hline kiai (気合?) [kiai] & $\begin{array}{l}\text { a shout before } \\
\text { conducting a martial } \\
\text { movement }\end{array}$ \\
\hline umami (旨味?) [umami] & delicious \\
\hline
\end{tabular}

(Bahasa, 2016)

\section{CONCLUSION}

According to the previous description, it is conluded that there are two Japanese morphological structures in Kamus Besar Bahasa Indonesia, $5^{\text {th }}$ edition, namely root structure and derivative structures. Root structure is a word consisting of one morpheme; while derivative structure is a word undergoing either affixation or compounding process.

The affixation process in Japanese loanwords is the addition of prefix ber- or pein the roots to create a new meaning. Moreover, the compounding process in Japanese loanwords found in Kamus Besar Bahasa Indonesia, $5^{\text {th }}$ edition are the combination of the word pemain with the word karate, the word pemain with the word judo, the word pelatih with the word karate, the word pelatih with the word judo, the word kanji with the word huruf, the word moci with the word kue, and the word bunga with the word sakura. Lexical meaning in Japanese loanwords are found in root structures, while the grammatical meanings are found in derivative structures.

There are three classes of Japanese loanwords found in Kamus Besar Bahasa Indonesia, $5^{\text {th }}$ edition that are 1) nouns, 2) verbs, and 3) adjectives. Noun is the most dominant class of word, originating in various names of things from diverse categories as culinary, culture, art, sport, military, and words created during the Japanese colonization in Indonesia.

The Japanese loanwords contained in Kamus Besar Bahasa Indonesia, $5^{\text {th }}$ edition have the same structures due to their customization with the Indonesian language. Those 
phenomenon happened for the reason that the vocabularies have been merged with Indonesian vocabularies for a long time.

\section{BIBLIOGRAPHY}

Bahasa, B. P. dan P. (2016). Kamus Besar Bahasa Indonesia. Retrieved from kbbi.kemdikbud.go.id

Chaer, A. (2013). Pengantar Semantik Bahasa Indonesia. Jakarta: PT Rineke Cipta.

Djajasudarma, H. T. F. (2013). Semantik 2 Relasi Makna Paradigmatik, Sintagmatik, dan Derivasional. Bandung: PT Refika Aditama.

Firdaus, W. (2018). Realisasi Pronomina dalam Bahasa Mooi: Analisis Tipologi Morfologi. Ranah: Jurnal Kajian Bahasa, 7(2), 180-193. https://doi.org/10.26499/rnh.v7i2.496

Indonesia, P. P. B. (2009). Pedoman Umum Pembentukan Istilah (3rd ed.). Jakarta: Pusat Bahasa.

Iriantini, S. (2013). Analisis Penggunaan Juju Hyougen dalam Bahasa Jepang. Ranah: Jurnal Kajian Bahasa, 2(2), 69--82.

Jerniati, I. (2013). Morfologi Bahasa Panasuan. Makasssar: Garis Khatulistiwa.

Kridalaksana, H. (2007). Kelas Kata dalam Bahasa Indonesia (2nd ed.). Jakarta: PT Gramedia.

Kridalaksana, H. (2008a). Kamus Linguistik. Jakarta.

Kridalaksana, H. (2008b). Kamus Linguistik.

Permadi, 1. Edo Galih, \& Murtiningsih, 2. Sri. (2015). Politik Bahasa pada Masa Jepang. Avatara, 3(3).

Sudaryanto. (1993). Metode dan Aneka Teknik Analisis Bahasa. Yogyakarta: Duta Wacana University Press.

Sugono, D. (2008). Bahasa dan Peta Bahasa Indonesia. Jakarta: Ministry of National Education. 